\title{
Towards effective youth participation
}

Magued Osman

Hanan Girgis

Follow this and additional works at: https://knowledgecommons.popcouncil.org/departments_sbsr-pgy

Part of the Demography, Population, and Ecology Commons, Family, Life Course, and Society Commons, International Public Health Commons, and the Politics and Social Change Commons How does access to this work benefit you? Let us know!

\section{Recommended Citation}

Osman, Magued and Hanan Girgis. 2016. "Towards effective youth participation," policy brief. Cairo: Population Council. 


\section{Towards Effective Youth Participation}

Magued Osman and Hanan Girgis ${ }^{1}$

\section{INTRODUCTION}

Egypt is a young country; one quarter of the population is between 12 and 22 years old, and another quarter is aged between 23 and 39. Those young people played a key role in the country's recent political changes; they were the fuel of the January 25 revolution, which ended with the successful removal of the political regime, and they imbued the revolution with a new, creative spirit and drew global attention through innovative practices such as graffiti, poetry and patriotic songs. Those practices were carried out by young people who showed the world their strong belief in the cause of a country that was striving for freedom, social justice, and the welfare of its citizens. However, although Egyptian youth amazed the world during the 18 days of the January 25 revolution, and again during the June 30 revolution, this has not had a significant impact on their political and social participation. This brief therefore aims to shed light on young people's participation in the aftermath of these revolutions, which embodied their hopes for greater empowerment and participation.

This essence of this brief stems from national and international concerns about young people's political participation. At the national level, the Egyptian constitution of 2014 includes several articles that guarantee freedom of political participation and encourages citizens to exercise this freedom. For example, Article 65 states that freedom of thought and opinion is legitimate, and citizens are free to voice their opinions by any means of expression or publication. Article 73 states that citizens have the right to organize public meetings, demonstrations, and all forms of peaceful protests. Article 74 guarantees citizens the right to form political parties, and Article 75 guarantees the right to establish non-governmental organizations. Moreover, Article 87 ensures the rights of citizens to vote, to stand for office, and to participate in referendums. The constitution also encourages political and social participation by young people specifically; Article 82 requires the state to guarantee the provision of care to young people and to endeavor to discover their talents, develop their abilities, encourage them to participate in group and voluntary activities, and enable them to participate in public life.

\footnotetext{
1 Dr. Magued Osman is the CEO and Managing Director of the Egyptian Center for Public Opinion Research (Baseera) and a Professor at the Department of Statistics, Faculty of Economics and Political Science, Cairo University. Dr. Hanan Girgis is the Operations Director of the Egyptian Center for Public Opinion Research (Baseera). The opinions expressed herein are those of the authors and do not necessarily reflect the views of the Population Council or the initiative supporters.
}

\section{HIGHLIGHTS}

- Data from various sources indicates that the political and social participation of young people in Egypt is in decline.

- The main reason for the reduction in political participation is the sense among young people that different forms of participation are meaningless. It is necessary to influence this attitude and for young people to be convinced of their ability to play a role in decisionmaking and in shaping public policy through different forms of participation.

- It is important to attract young people to political participation by involving them in following up and evaluating the implementation of government policies and programs at the national level, as well as employing different technologies to facilitate this participation.

- There is a need for a comprehensive plan for the development of the Egyptian media in order to push it to play a positive role in shaping young people's political knowledge and attitudes about civic engagement.

\section{POPULATION
COUNCIL \\ Ideas. Evidence. Impact.}


In addition, the national strategy for sustainable development, Egypt's Vision 2030, incorporates many objectives that focus on the enhancement of young people's lives, either directly or indirectly ${ }^{2}$. President Abdel-Fatah Al-Sisi has also named 2016 as the official "year of the youth", and the president's office has put in place a youth leadership program, the first cohort of which includes around 500 young people.

At the international level, Egypt has signed up to the United Nations' sustainable development goals, which include 17 goals and 169 outcomes. The tenth goal specifically reaffirms the importance of increasing political participation of citizens of all ages and of putting in place laws to help achieve this. ${ }^{3}$ In addition, in 2012 the secretary-general of the United Nations developed a five-year plan for his second term which included the realization of five main goals, among them the political, social, and economic integration of young people. ${ }^{4}$

\section{DATA SOURCES}

This brief relies on data from the following recent surveys:

- The second round of the Survey of Young People in Egypt (SYPE) conducted by the Population Council in collaboration with the Central Agency for Public Mobilization and Statistics (CAPMAS) in 2013/2014. SYPE re-interviewed a sample of 10,916 young men and women aged between 13 and 35 .

- The Arab World Social and Political Transformation Survey conducted by Baseera in November 2014 through face-to-face interviews with a nationally representative sample of 1,547 individuals aged 18 and above from all over Egypt.

- The Political Participation Poll: Perception and Practices conducted by Baseera as part of its Masar Project in 2015. The poll was conducted through telephone interviews, using both landlines and mobile phones, with a nationally representative sample of 2,027 individuals aged 18 and above from all governorates of Egypt.

- The 2014 Post-Presidential Elections Poll conducted by Baseera through personal interviews with a sample of 12,940 voters as they exited polling stations located throughout Egypt, excluding the border governorates.

- Two Pre-Parliamentary Elections Polls conducted by Baseera before the 2015 parliamentary elections. The polls were conducted through telephone interviews, using landlines and mobile phones, with a nationally representative sample of 1,545 individuals aged 18 and above from all governorates of Egypt.

- The Post-Parliamentary Elections Poll conducted by Baseera in 2015 through personal interviews with a sample of 4,086 voters in the first phase of the elections and 7,200 voters in the second phase, conducted as they exited polling stations throughout Egypt, excluding the border governorates.

\section{INTEREST IN POLITICS AND POLITICAL PARTICIPATION AMONG THE YOUTH}

Although young people played a major role during the 2011 and 2013 revolutions, their participation in referendums and elections is low. For example, data from the 2014 Presidential Elections Poll indicates that the share of young people aged $18-30$ who actually voted constituted only $27 \%$ of total interviewed voters, although this age group makes up around $37 \%$ of eligible voters (Figure 1). Similarly, low youth participation was documented during the more recent parliamentary elections in Egypt, with figures not exceeding more than $20 \%$. Furthermore, according to the two polls conducted by Baseera before the 2015 parliamentary elections, only $4 \%$ of young people knew the correct dates of the elections in their governorates during the first phase of voting, and only $29 \%$ knew the dates during the second phase.

\footnotetext{
2 Sustainable Development Strategy 2030: http://sdsegypt2030.com/.

3 See http://www.undp.org/content/undp/en/home/sdgoverview/post-2015-development-agenda.html.

4 Enhancing Youth Political Participation throughout the Electoral Cycle, UNDP, 2013.
} 
FIGURE 1: Distribution of eligible voters and the voters who participated in the 2014 presidential elections by age

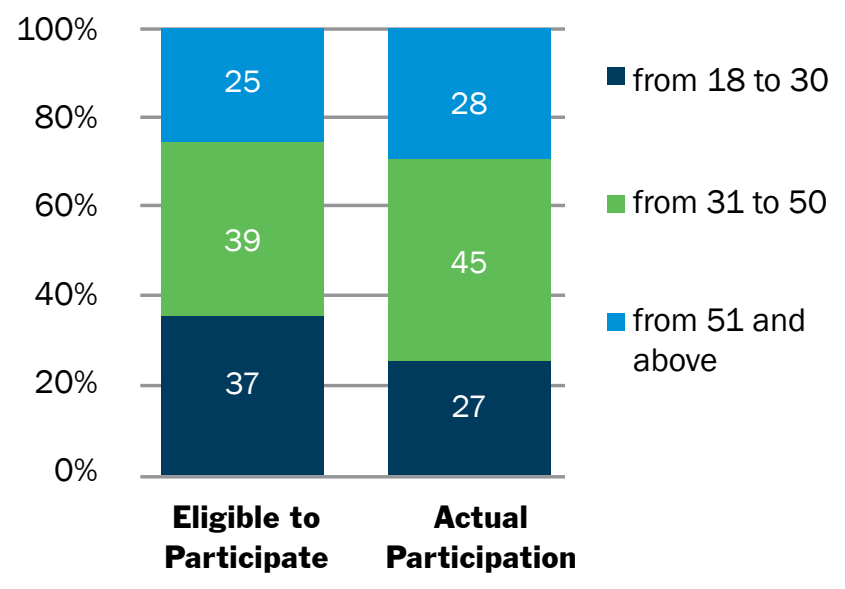

Sources: Eligible voters calculated from the Statistics of the Electorate, the Supreme Committee for Elections. Actual participation calculated from the 2014 Presidential Elections Poll carried out by Baseera.

Even though young people were reportedly among those least satisfied with the performance of the previous president Mohamed Morsi, the number of Egyptians aged 18-29 who participated in protests or demonstrations or signed the Tamarod ("Rebellion") petition opposing his presidency did not exceed $1 \%$. This is attributed, for the most part, to their uncertainty as to whether such actions were the right thing to do. Moreover, the 2014 Survey of Young People in Egypt shows that one out of every six young people believes that it is useless to participate in politics. The survey also asked young people to rate their interest in politics, with only $17 \%$ of respondents describing themselves as interested or very interested in politics, and only $28 \%$ saying they followed political news.

\section{CONFIDENCE IN THE VALUE OF POLITICAL PARTICIPATION}

This reluctance of young people to participate in politics conflicts with the results of the 2015 Political Participation Poll: Perception and Practices, which show that over half of those surveyed who were aged 18-29 believe that political participation has an effect on governmental decisions, and $86 \%$ believe that political participation is essential to create and support democracy in a country.

This contradiction may be due to the fact that young people do not feel the direct value of the various forms of political participation in Egypt. In fact, less than half of young people think that voting in elections is an effective way to participate in politics, and can affect policy. In addition, three out of every ten respondents think that joining political parties are a reliable form of political participation, while one out of three thinks that protests and demonstrations and one in every six thinks that sit-ins and civil disobedience are an effective way to participate.

According to the 2014 Survey of Young People in Egypt, participation in political parties has yet to draw the interest of young people, which may be due to their lack of knowledge of the different party programs. The Arab World Social and Political Transformation Survey also reveals that $43 \%$ of Egyptian youth are not satisfied with the way that democracy is developing in Egypt. This latter survey also shows that there is a relationship between young people's reluctance to participate and their belief that some of the objectives of the January 25 revolution have not been achieved. For example, on the economic well-being front, a significant percentage of young people believe that their family's economic status and that of the country as a whole was worse at the end of 2014 than before the revolution. They also feel that minimal improvements have been achieved with regards to ensuring social equity. In addition, around $66 \%$ of young people think that corruption exists in governmental institutions to a very large degree, while $24 \%$ believe it exists at a moderate level. For young people the use of wasta, or personal connections, to obtain a job is also of particular concern; almost $55 \%$ of those surveyed in the 2014 Survey of Young People said that jobs are obtained by wasta to a large extent and 30\% said that jobs are obtained by wasta to certain extent.

\section{TECHNOLOGY AND POLITICAL PARTICIPATION}

Technology has affected the political situation in Egypt to a large degree in recent years; in particular, the internet and modern communication methods played a very large role in the January 25 revolution. Based on the Survey of Young People, internet use among young people aged (15-29) increased dramatically from $10 \%$ in 2009 to $25 \%$ in 2014 . Furthermore, on average, young people who participated in the revolutionary activities rated TV, internet news and Facebook as the three most important source of information to them during the January revolution, at $7.3,7.1$ and 6.4 , respectively (Figure 2). 
Most young people believe the internet can have a large impact on politics (Figure 3). Almost $90 \%$ of young people think that the internet will change the ability of citizens to affect government policy, while $87 \%$ think that the internet will help citizens to find out more about what the government does, and $89 \%$ think that it will enhance the process of expressing citizens' opinions about the government. On the other hand, $82 \%$ of the participants agreed that politicians will use the internet to affect citizens. In addition, a quarter of young people believe that activity on social media networks is a very effective way to participate in politics, and can affect government decisions. Additionally, the results of the Arab World Political and Social Transformation Survey indicate that $77 \%$ of young people who use social media networks actually use them to gain information about current political issues, and $41 \%$ use them to comment on different political issues.

FIGURE 2: Young People's, who participated in the revolution, rating of the importance of different media sources of information about January 25 (scale of 1 to 10), 2014

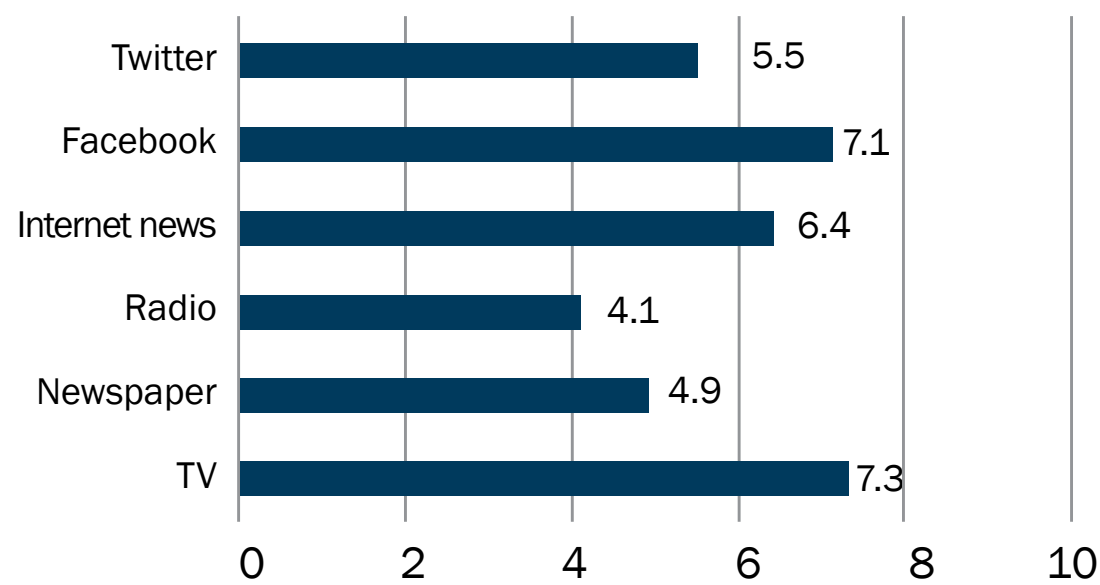

Source: The 2014 Survey of Young People in Egypt.

FIGURE 3: Young people's opinions on the impact of the internet on citizens' ability to affect government policy, 2014

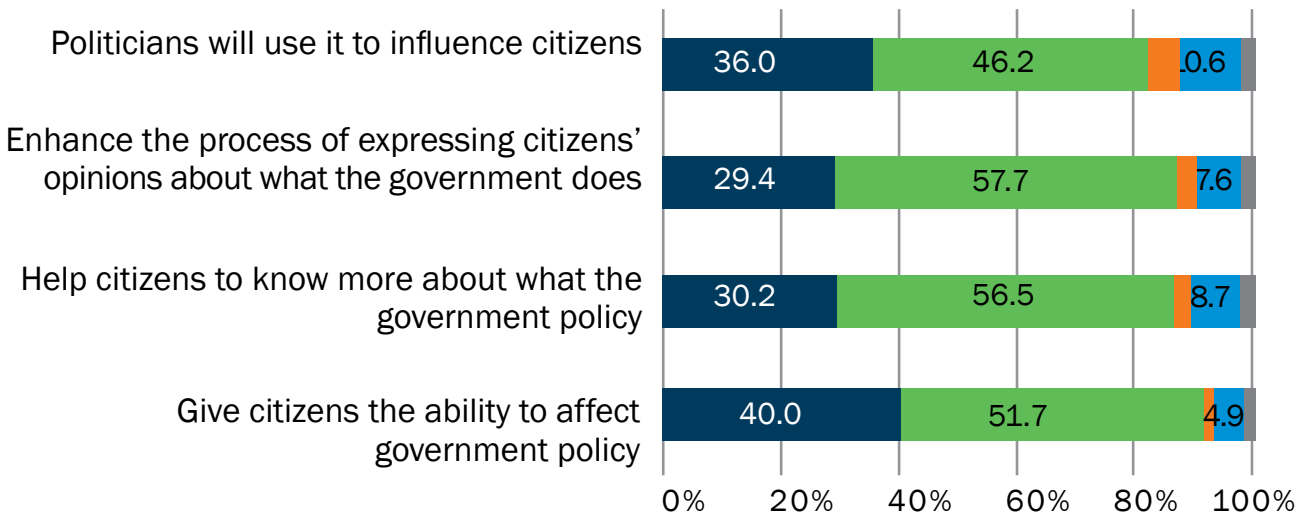

\section{Totally Agree Agree Indifferent Disagree $\quad$ Totally Disagree}




\section{CIVIC ENGAGEMENT}

Voluntary work is often associated with charity work in the minds of young people. When the 2014 Survey of Young People asked about the best definition for volunteering, $57.6 \%$ of the interviewed young people defined it as "providing assistance for the poor and marginalized", $14 \%$ as "bringing people together and building solidarity", and another $13 \%$ as "helping people to develop their skills." According to only $6 \%$ of young people, volunteering meant "empowering individuals or communities" or "encourage active citizenship."

FIGURE 4: Young people's opinion of what volunteering means, 2014

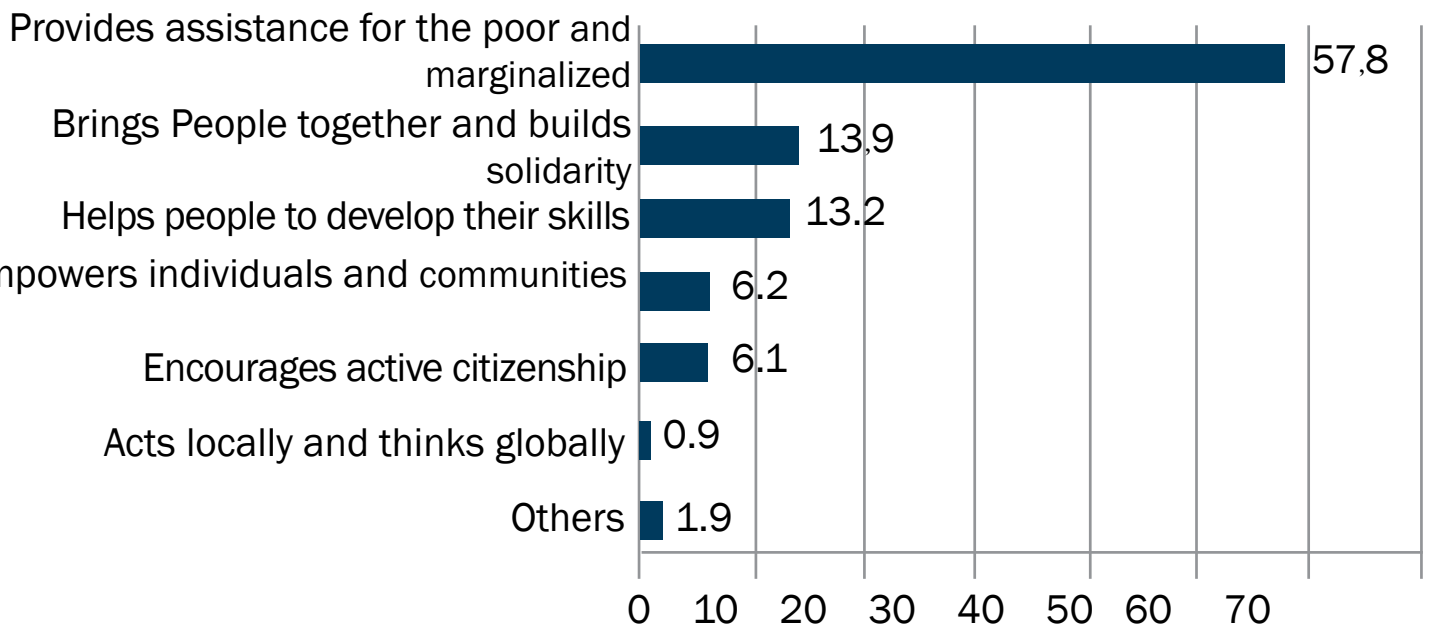

Source: The 2014 Survey of Young People in Egypt.

Even within this limited definition, youth civic participation is very minimal in Egypt. The 2014 Survey of Young People in Egypt shows that only 2\% of young people are members of charitable organizations, while the rate of young people involved in voluntary work was about the same. The reasons provided by young people for their low rate of participation were lack of time and money, as well as discouragement from their families. In addition, the percentage of young people who are members of syndicates or labor unions does not exceed $5 \%$, which may be due to the fact that members of such organizations must be employed.

\section{POLICY RECOMMENDATIONS TO INCREASE CIVIC AND POLITICAL PARTICIPATION AMONG YOUNG PEOPLE}

There are many opportunities to empower young people and increase their participation by, for example, holding seats as delegates in the parliament and in the local assemblies, as stated in the constitution. Also, ensuring that some deputy ministers and ministerial aides are young people would give an indication that, in the near future, there will be more space for youth participation in decision and policy making in Egypt.

Other policy measures we see as mandatory to increase political and civic participation among young people are as follows:

\section{Opening up new platforms for youth participation:}

increasing youth participation requires changing attitudes regarding the value of participation through opening up new pathways that allow them to play a real role in shaping policy and affecting government decision-making. Those platforms may take the following forms: 
- $\quad$ Formulating committees of young people under the umbrella of the parliament and the local councils. The role of those committees would be to monitor and evaluate the implementation of different policies and programs in a handson way, and to report back on their findings. The committees could also hold meetings with young people to listen to their problems and seek solutions.

- Making use of young people's interest in the internet, especially social media platforms and telecommunications, by developing new technologies that allow users to send a notification if they encounter any adverse phenomena such as violence, corruption in its different forms, or street children in need of assistance. Documenting such negative phenomena is a first step towards combating them.

- $\quad$ Creating channels for young people to participate in the preparation of governmental programs and commenting on program plans through social media or through websites that would enable them to communicate their opinions to the government.

- Using youth training centers, cultural places and summer camps to gather young people with different members of the government, the parliament, and specialized committees to discuss different social issues pertaining to youth and their possible solutions.

\section{Enforcement of the constitution:}

- $\quad$ There are many articles in the Egyptian constitution that aim at increasing the political and social participation of different groups; however, the implementation of these articles requires the development of new laws and their application on the ground. For example, local non-governmental organizations, particularly smaller ones, face several logistical problems when carrying out work in Egypt, although NGOs are among the main streams that could be used to direct the energy and creativity of young people towards solving the problems facing their local communities. This calls for updating the laws that control the establishment of NGOs and organize their framework of activities.

\section{Activation of the role of traditional media in increasing youth participation of different Egyptian issues:}

- In recent years many Egyptians, especially young people, have stopped following the traditional media channels, perhaps due to their lack of coverage of young people's daily problems. Also, most of those media channels are Cairo-centric and neglect problems faced by remote governorates and rural parts of Egypt. In addition, the Egyptian drama and film industry ignores the positive role which Egyptian youth could play in the country's development and focuses instead on portraying negative examples. This had made the media lose its important traditional role in educating and cultivating good ethics among young people.

The Ministry of Youth and Sport has created a website called "The Youth's Portal on the Egyptian Parliament" which includes information on the parliament, its members, and relevant news. It is suggested that a page be added to the website where young people can express their ideas and communicate them to members of the parliament. The page could also allow young people to provide their assessments and comments on the performance of the parliament. 
- It is therefore important to put in place a complete plan to help develop the Egyptian media and push it to play a positive role in shaping young people's knowledge, changing their values, and encouraging them to actively participate in the country's political and social issues. The media should also play a major role in challenging the misconception that young people are not able to take on greater responsibilities and authority.

4. The role of the Ministry of Youth and Sport in youth political and civic participation:

- $\quad$ The Ministry of Youth and Sorts should play a more active role in the development of civic and political participation among young people through the activation of youth centers and the establishment of social communication platforms to interact with young people.

5. The role of political parties and NGOs:

- $\quad$ Political parties and NGOs should re-design their programs and activities to better attract young people. 
The Population Council confronts critical health and development issues-from stopping the spread of HIV to improving reproductive health and ensuring that young people lead full and productive lives. Through biomedical, social science, and public health research in 50 countries, we work with our partners to deliver solutions that lead to more effective policies, programs, and technologies that improve lives around the world. Established in 1952 and headquartered in New York, the Council is a nongovernmental, nonprofit organization governed by an international board of trustees.

Population Council

One Dag Hammarskjold Plaza

New York, NY 10017

Population Council/Egypt

59 Misr-Helwan Agricultural Road, Maadi

PO Box 168, Maadi

Cairo, Egypt 11431

Tel. +20225255968

Fax: +20225255962

popcouncil.org

Suggested citation: Osman, Magued and Hanan Girgs.2016. “ Towards Effective Youth Participation.” Cairo: Population Council.

(c) 2016 The Population Council, Inc

\section{POPULATION} COUNCIL

Ideas. Evidence. Impact.

SUSAID

UN Volunteers mecistom in weter
(2) FORDFOUNDATION

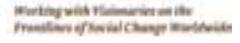
SWEDEN

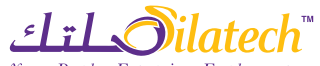

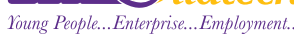

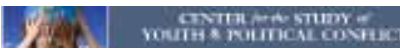

\section{$\because$ Writ unicef(3) \\ WOMEN \\ WOMEN}
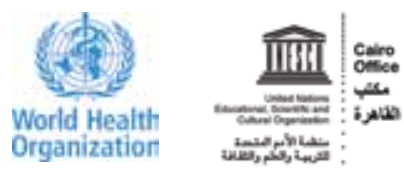

(2) UNAIDS D.P

nonsins 